\title{
ECONOMIC AND SPATIAL STRATEGIES OF ARTISTS AS CULTURAL ENTREPRENEURS
}

\author{
Monika Murzyn-Kupisz @ , JarosŁaw DziaŁeK ๑ \\ Department of Regional Development, Jagiellonian University in Kraków, Poland
}

Manuscript received: March 31, 2019

Revised version: July 18, 2019

\begin{abstract}
Murzyn-Kupisz M., Dziatek J., 2019. Economic and spatial strategies of artists as cultural entrepreneurs. Quaestiones Geographicae 38(4), Bogucki Wydawnictwo Naukowe, Poznań, pp. 29-47. 1 table, 1 fig.

ABSTRACT: The text aims to explore the economic and spatial strategies followed by artists who run micro-firms. The authors analyse results of a qualitative study of independent artist enterprises in Kraków. It reveals that motivations for artistic entrepreneurship are diverse and foremost linked with the need to overcome challenges artists experience in the labour market and in the market for cultural goods and services. Different strategies translate into particular location choices as well as varied visibility of such firms in urban space.
\end{abstract}

KEY WORDS: artists, entrepreneurship, strategies, location, urban space

Corresponding author: Monika Murzyn-Kupisz, Jagiellonian University in Kraków, ul. Gronostajowa 7, 30-387 Kraków, Poland; e-mail:monika.murzyn-kupisz@uj.edu.pl

\section{Artistic entrepreneurship as a potential focus of research linked with the creative economy and urban transformations}

In recent years there has been a growing interest among decision makers and researchers in the creative sector and the cultural economy as an important aspect of contemporary urban transformations (Montgomery 2007; Krätke 2011; Pratt, Hutton 2013; Hutton 2016; Chapain, Stryjakiewicz 2017). At the same time, it has been noticed that the creative economy is a challenging topic to study due to its economic and cultural dualism (Kolb 2015) and specific mechanisms which are linked with its present-day functioning such as the issues of embeddedness, semiotisation, commodification of cultural contents and values and their circulation, digitisation and globalisation (Stachowiak 2017). The diverse approaches to the creative economy include more conventional studies of cultural institutions, the perspective of the creative city, the creative sector, artistic and cultural professions or cultural policies (Grodach 2013). Studies on artists are rarely undertaken taking into account the possibility of using overlapping perspectives and the spatial-economic dimension of their presence in cities.

Advocates of taking a closer look at artists' residential and professional choices in cities therefore point to the need for a broader inclusion of artists and their activities in studies on urban development, of potential use not only to academics, but also to public policy makers (Markusen 2014). Moreover, individual artistic activities tend to be regarded from a purely 
cultural and symbolic point of view, while more general studies referring to artists are prone to focus on selected areas of artists' presence within cities (e.g. quarters perceived as artistic) (Hracs 2009; Heebels, van Aalst 2010; Zukin, Braslow 2011; Debroux 2013; Działek, Murzyn-Kupisz 2014), cultural institutions employing them and presenting the outcomes of their creative efforts or production, consumption and circulation of artworks. Fewer studies have been undertaken with respect to artists acting as cultural (artistic) entrepreneurs (culturepreneurs) in urban space (Heebels, van Aalst 2010; Suwala 2015; Cunningham, Tolonen 2019). This is surprising taking into account that artists are almost 'by definition' enterprising individuals (Scherdin, Zander 2011) who often take risks implementing novel, subjective ideas and translating them into artworks, creative goods and services, without being certain of their outcomes, social acceptance or commercial success. They have to interact with external observers, encounter critics, imitators and followers. They need to display a dose of leadership, be persistent and active to leave a mark in the artistic field or at least to survive in it, both in economic and in artistic terms (Menger 1999; Swedberg 2006; Blaug, Towse 2011). On the one hand, there is an insufficient amount of research on entrepreneurial aspects of artistic work of potential use to non-artistic entrepreneurs (Scherdin, Zander 2011). On the other hand, the need for gaining entrepreneurial knowledge and practical skills has been increasingly noticed both by art schools and art school graduates and by researchers of creative industries (BogaczWojtanowska et al. 2018). From this point of view artists are not by definition entrepreneurs in conventional terms, but they frequently do decide or are forced to display economic entrepreneurship qualities and attitudes in order to function in the art market, face market challenges or implement artistic ideas (Leadbeater, Oakely 1999; Oakely 2014; Kolb 2015).

Although studies on the creative sector in Poland, in particular creative industries, point to the dominance of micro-firms in the overall structure of firms, in-depth studies of such firms are rare and limited to general statistical data on the city, regional or national level (e.g. Namyślak 2013; Stryjakiewicz et al. 2014) or general issues linked with location factors (Tomczak,
Stachowiak 2015). In turn, research on artistic entrepreneurship in other countries has usually been conducted at most on a metropolitan level, rarely including intraurban patterns. If so, it most often pertained to a selected discipline, a particular creative sector branch such as visual arts (Pasquinelli, Sjöholm 2015) and music (Aggestam 2007; Scott 2012), traditional types of artistic entrepreneurial activities (e.g. art galleries, music and theatre venues), larger endeavours linked with creative industries or a single urban area (Heebels, van Aalst 2010). It likewise tended to focus on collective artistic endeavours or strategic usage of virtual space, especially for the purpose of networking, gaining tacit knowledge, professional identity creation (Leadbeater, Oakley 1999; Pasquinelli, Sjöholm 2015) or instrumental uses of culture in the processes of urban regeneration (Montgomery 2007; Kim 2016).

Considering the above research foci as a knowledge gap, our study aims to creatively combine several strains and approaches to artists' entrepreneurship, presence and activities in cities in order to examine and analyse economic and spatial strategies of artists as cultural entrepreneurs. To achieve this goal we will focus on the cases of artists who come up with, original and novel, especially in the Polish urban context, forms of activities which involve implementation of creative ideas, stabilising and diversifying income from artistic and non-artistic activities or testing new organisational solutions. We will take into account both visible and only partly visible or invisible presence of artistic entrepreneurs in urban space. Accordingly, recognising the importance of focusing on their individual spatial practices (Pasquinelli, Sjöholm 2015: 80), the following main research questions were posed:

- What are the motivations for undertaking entrepreneurial activities by artists who run micro-firms in Kraków?

- What factors impact on their location in specific parts of the city?

- To what extent are their location decisions linked with social and professional networks?

- What are the economic and spatial consequences of particular spatial choices of artists undertaking entrepreneurial activities?

The remainder of the article is structured in the following way. The second section of the text is focused on the review of literature on 
entrepreneurial attitudes and practices of artists as well as the spatial aspects of their functioning in cities. Next, the research methodology and the analytical framework used in the analysis of empirical findings are introduced. The subsequent part presents ten case studies of artistic entrepreneurs running firms in different parts of Kraków. The paper concludes with a synthetic discussion of research results, in particular economic and spatial strategies followed by culturpreneurs in the city.

\section{Artists as cultural entrepreneurs}

Many artists who run firms in the cultural or creative sector fit the basic dictionary definition of an economic entrepreneur as "someone who starts their own business, especially when this involves seeing a new opportunity" (Cambridge Dictionary 2019). Blaug and Towse (2011: 157) offer a more precise definition whereby:

"A cultural entrepreneur is an innovator, usually but not necessarily an individual, who generates revenue from a novel cultural activity. Cultural entrepreneurs do much more than manage the activity; typically they discover it and exploit its revenue potentialities. They have the one quality (...) namely alertness to revenue generating arbitrage, involving either new products, new materials, new processes or all of these in some combination."

Rae's (2007: 55) understanding of creative entrepreneurship as: "creating or identifying an opportunity to provide a cultural product, service or experience and bringing together the resources to exploit this" seems useful, too. Suwala (2015) therefore distinguishes three different components of successful cultural entrepreneurship: the creative aspect of it linked with initiating novel ideas, forms, methods or frameworks of artistic expression, the functional aspect linked with their actual implementation, social acceptance and promotion, and the 'productive' component understood as the ability to economically valorise ideas, cultural goods and services. Engaging in creative entrepreneurship artists therefore have to combine and reconcile between, at times conflicting and blurred, identities: that of an artist and that of a small business owner, between artistic and commercial cultures (Kim 2016; Cunningham, Tolonen 2019). Artistic businesses often require multi-skilling as they frequently integrate in a hybrid form the sale of cultural goods and services with more commercial activities such as running a café or an events' venue (Leadbeater, Oakley 1999). This idea is broadened to include a spatial dimension by Lange (2009: 116) who views a culturepreneur as

"an urban protagonist who possesses the ability to mediate between and interpret the areas of culture and of service provision (...) who is transparently multi-skilled and ever willing to pick up new forms of expertise (...) who runs clubs, record shops, fashion shops, galleries and other outlets, who closes gaps in the urban landscape with new social, entrepreneurial and socio-spatial practices."

Culturepreneurs understood in such a way are not only important in shaping new functions and providing novel services in urban space but “(...) play a decisive role, acting as key agents by providing, knowing and inventing new urban narrations" (Lange 2009: 129).

One of potential motivations for artists to become entrepreneurs might be inherent challenges artists encounter in the labour market where there is a permanent oversupply of artistic labour (art school graduates and self-made artists) in comparison to limited demand for it (Towse 2010). This translates into instability and irregularity of incomes, flexible employment, freelancing and multiple job holding of both artistic and non-artistic character, obtaining income from many sources and in diverse forms. Consequently, "Precarity, freelancing and entrepreneurship are key features of artists' and other creative workers' constant search for resilient paths throughout their professional lives" (Pasquinelli, Sjöholm 2015: 77). Artistic freelance and micro-entrepreneurial activities are then a part of artists' strategies of professional resilience involving various spatial practices beyond institutionalised forms of artistic activity.

Artists' motivations for entrepreneurial activities are diverse taking into account that the overall value of what they create is not only economic but also cultural (Throsby 2001). Apart from financial rewards, non-monetary rewards and intrinsic motivations seem to be a much more 
important driving force for them than for other professionals (Swedberg 2006; Blaug, Towse 2011). Artists usually prefer to work more than less and derive satisfaction from work as a means of personal development and self-fulfilment or gaining appreciation in the artistic milieu, though at the same time they often deal with a relative economic scarcity (Scott 2012).

Two distinctive perspectives are mentioned in the literature on the clustering of creative firms referred to as representational and non-representational respectively. The first emphasises geographical proximity of amenities and people, the second stresses the symbolic meanings and inspiration provided by the urban environment (Heebels, van Aalst 2010). The practical (utilitarian) considerations seem to be important location factors especially to newly established or avant-garde creative entrepreneurs termed starters and experimenters (Heebels, van Aalst 2010). The image related motivations connected with the wish to strengthen a creative reputation matter for a greater number of culturpreneurs. A study on the location of art galleries in Barcelona underlines similar features as important for their spatial strategies, namely access to the desired type of customers and image of particular urban spaces which may be used by gallery owners to build a given gallery's identity and symbolic capital. Location in or nearby artistic clusters is their pragmatic choice linked with the need to minimise risks associated with the shortcomings of the art market and artists' labour market (RiusUlldemolins 2012).

The spatial dimension of artistic entrepreneurship is often overshadowed by general assumptions on artists' predilection for buzz-rich bohemian neighbourhoods offering access to informal cooperation networks, collaborative projects, tacit knowledge, opportunities for developing a distinct socio-spatial identity or attract attention (Hracs 2009; Lange 2009), or reduced to impact of rental prices on artists' choices. According to Hracs (2009), this leads to overlooking artists who live or work in more mundane, every-day locations not associated with an artistic image. What is more, artists are often expected to combine their place of work and residence; they are not only to congregate in larger urban centres, but they are also supposed to cluster in 'live-work' quarters (Wedd et al. 2001). For example, artistic entrepreneurs in Great Britain are believed to "prefer mixed-use neighbourhoods in which they can work, socialise and live" (Leadbeater, Oakely 1999: 35).

Similarly, Pasquinelli and Sjöholm (2015) posit that networking and bonding, proximity to peers and opportunities for strengthening social capital in collective spaces are key for resilient artistic careers whether as freelancers or micro-entrepreneurs, especially for early career and avant-garde artists. The issue of the specific local context enabling face-to-face contacts with other artists, cultural intermediaries and customers is also emphasised by Suwala (2015: 514) who terms it "spatial and cognitive proximity to cultural districts, milieus or neighbourhoods" and Cunningham and Tollonen (2019: 5) who develop the concept of mixed embeddedness and understand the "entrepreneurial activity as a phenomenon nested in localised patterns of social and institutional relations". Dependence on localised knowledge and non-declared, informal exchanges of services are also stressed.

Other issues such as the diversity of potential spatial and non-spatial strategies, needs and attitudes with respect to direct encounters with and proximity to clients or desired features of artists' workplaces are rarely explored. They are therefore believed to be likely to opt for attractive inner city, historic or post-industrial quarters perceived as artistic and appreciate all of the constitutive qualities of such areas such as a mix of functions, diverse bohemian amenities, artistic buzz, an interesting cultural landscape and a distinctive image - a specific 'look and feel', both in the case of 'planned' and spontaneously developing artistic hubs (Montgomery 2007; Heebels, van Aalst 2010; Smit 2012).

Yet the very same authors might also in a somewhat contradictory fashion notice that artists may follow different strategies of intended visibility, partial visibility or invisibility in urban space (Lange 2009). Moreover, engaging in entrepreneurial activities, creatives might consciously decide to focus on their own, original artistic creation as such and selling its outcomes, on being an intermediary between other artists and the commercial world, limit own artistic creation but provide opportunities for recognition and financial viability of other artists' work or put greater emphasis on economic growth rather 
than artistic outcomes with the principal aim to run a commercially successful creative artistic business. If the first two orientations are usually linked with strong embeddedness in a specific local artistic milieu and engagement with the surrounding creative scene, in the case of the third approach such engagement is less likely or weaker (Cunningham, Tolonen 2019).

\section{Research methodology and design}

Our study is based on qualitative data gathered in 2015-2019 through semi-structured indepth interviews with ten artist entrepreneurs who use (usually rent) workspace in different parts of Kraków. The geobiographic method (Karjalainen 2003) was used to inquire about their motivations, economic model and location decisions in urban space with respect to the running of micro-firms based on their artistic skills and experiences. They represent various art disciplines: visual arts (graphic arts, painting, photography), design (fashion, furniture, jewellery), literature and publishing. Most of them (7) were selected out of a larger pool of artists (37) who were interviewed within a broader project focused on their spatial choices and role in post-socialist cities. Artists who undertook imaginative entrepreneurial activities, beyond usual artistic practices came out as a particularly interesting group, especially taking into account additional factors which impact on their spatial strategies and are linked with their engagement in entrepreneurial activities. Some of them combine artistic activities with a gallery, souvenir shop, café or workshop function, others focus on the creation and distribution of their original artworks and design items. The original set of $7 \mathrm{mi}-$ cro-firms was complemented by additional three interviews conducted in 2019 in order to ensure a varied representation of entrepreneurial endeavours both in terms of artistic disciplines and their location in different parts of the city (Fig. 1). All of them have been founded at least five years prior to the interview (one established in 2002, others in 2011-2014) which may be understood as a reflection of their relative longevity and success in commercial terms, especially taking into account the short lifespan of many firms in the creative

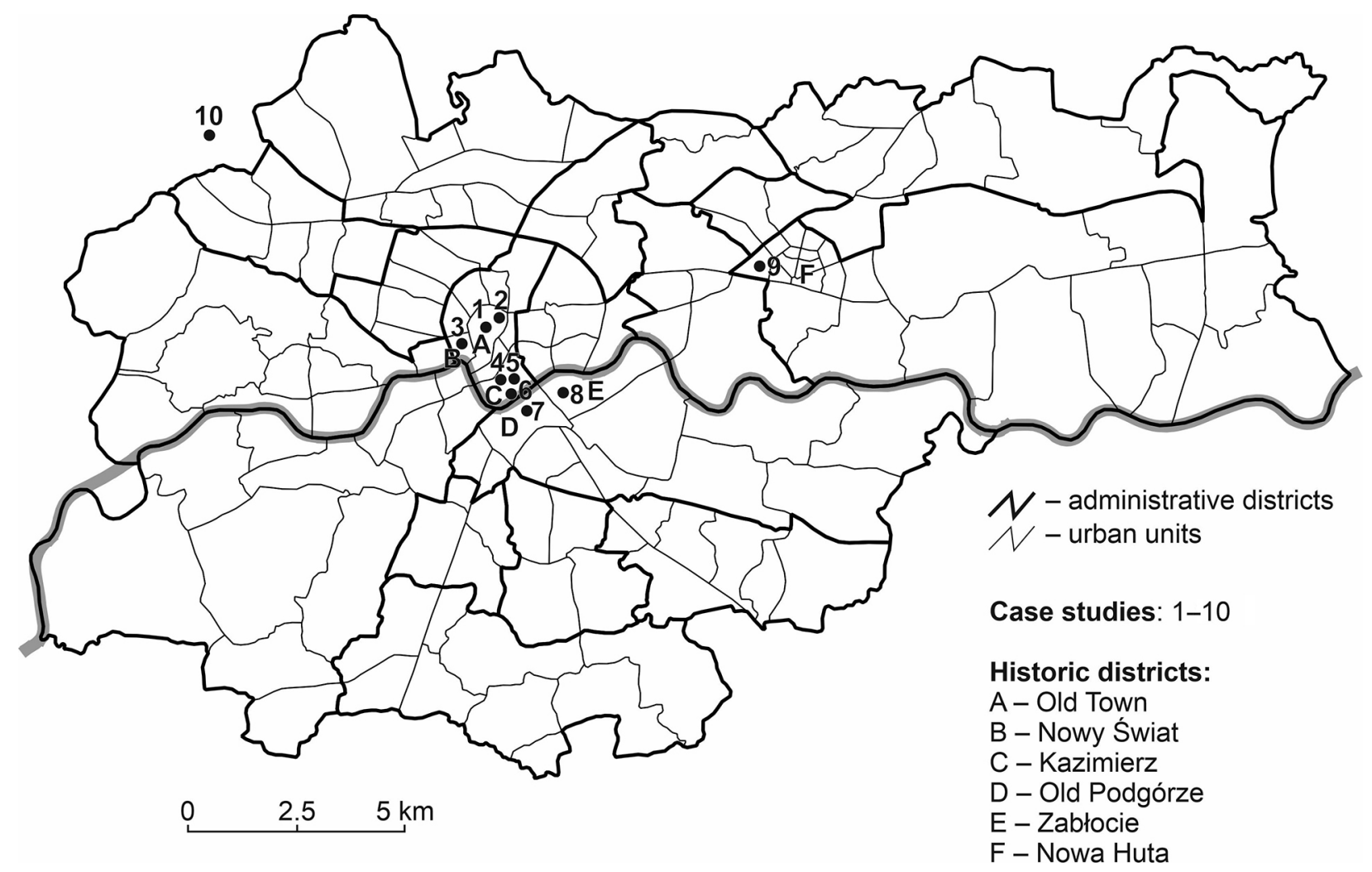

Fig. 1. Location of case studies in Kraków. Source: own elaboration. 
sector. In addition, in our opinion, the majority of them have come up with a relatively novel formula of an artistic business (in the context of Kraków and at the moment of their establishment), which makes the examination of economic and spatial strategies behind their foundation and location all the more interesting.

Kraków is the second largest Polish city, commonly associated with artistic education, cultural events and cultural life, often dubbed 'the cultural capital of Poland' both due to its rich material and immaterial heritage and continuity of artistic importance on the national level. It is also considered one of Polish cities with the highest concentration of creative firms (ŚrodaMurawska, Szymańska 2013) and professional artists (Murzyn-Kupisz, Działek 2017a). Thus, it seems interesting to see to what extent artists, in particular culturpreneurs, draw on the heritage and genius loci of different parts of the city, make use of the diversity of meanings associated with them, sustain or creatively transform them. By doing so, they may contribute to the creation of new spatial values and urban scenes and become an important force which changes the city's urban landscape and contributes to the regeneration of its selected quarters.

The case studies of artistic entrepreneurs in Kraków will be presented starting from the city core and moving away from it towards the outskirts of the city (Fig. 1) using a typology of quarters proposed by Murzyn-Kupisz and Działek (2017a: 546-548). They will follow the perception of artistic quarters in Kraków and their evolution: starting with the medieval city centre - the Old Town as the foremost inner city quarter of artistic memory and traditions, moving to Kazimierz as a historic district considered the most important area of independent cultural activities with a clear artistic image, then to Podgórze and Zabłocie as potential or ephemeral artistic quarters to which artists started to spontaneously move in the recent two decades but where commercial investments are quick to exploit and push out artistic uses making the two areas unlikely to transform into mature cultural quarters (Działek, Murzyn-Kupisz 2014). Such case studies of artistic entrepreneurship in 'expected' areas of artists' presence will be counterbalanced by cases of artist-run firms which are not located in quarters associated with visible, actual or potential artistic developments, located in less known parts of the broader Kraków downtown (prestigious, more well-to-do areas of artistic residence and production) or in other, newer, more peripheral areas without an artistic image (suburban residential areas, post-socialist housing estates). The reason for their inclusion is that, despite dominant perceptions on artists' places of residence and work and expectations of their propensity to cluster in selected areas, both quantitative data on the location of creative firms in Kraków representing sectors most likely to employ professional artists and national census data on professional artists' places of residence point to much greater than expected dispersion of artists throughout urban space as well as their relative overrepresentation in some well-to-do areas without an artistic image or greater visibility of artistic endeavours (e.g. prestigious 19th and early 20th century quarters west of the city centre, peripheral housing estates from communist times and a post-communist time). Data on venues of cultural events in Kraków also points to the increasing dispersion of artistic activities away from the city centre to newer areas of artistic presence (Kazimierz, Old Podgórze) or to other quarters, though the broader historic downtown still remains their focal point (Murzyn-Kupisz, Działek 2017a).

\section{Case studies of artistic entrepreneurs in Kraków}

\section{Artists finding an entrepreneurial niche in the mediaeval city centre}

Case study 1: Kacper Ryx Historical Shop currently functions as the main physical distribution place for books of Mariusz Wollny, a writer who lives and works in Kraków (in one of newer, peripheral quarters). Educated as an ethnographer, and having completed post-graduate studies in history, while working as a history teacher, he started to write popular history books for children and youth and then achieved a broader recognition thanks to a series of historical crime novels set in the context of 16th century Kraków and presenting the adventures of the royal 'investigator' Kacper Ryx. Popularity of this literary genre in Poland, coupled with imaginative depictions of life in the early modern city and the 
fact that most of the described places still exist in the 'real' city, contributed to the series' success. Meanwhile Wollny quit his job as a teacher and together with his wife decided to open a shop thematically linked with his books. The venture was based on some previous retailing experiences (a shop with folk arts and crafts in the outskirts). The shop opened in 2012 in the very city centre in a changed formula as a 'historical shop' focused on the promotion of books by Wollny and sale of related souvenirs, contemporary handmade 'historical' articles such as clothing, leather articles, figurines, goblets and pieces of armour.

Although with time the couple learned that sales of original handmade articles are not a sufficient source of income, the shop had to downsize and started sharing space with another vendor, it proved to be an excellent base for all activities linked with Wollny's literary creation and a major aspect of his business strategy as an author. The shop and the connected independent publishing house JaMa (founded in 2014) are reliant on the artistic production of Wollny (publishing new books, new editions) as well as his personal skills as a charming and talented storyteller, guide and speaker. This is a family business in which the core artistic creation is supported by the direct involvement of his family members engaged in editing and illustration of his books, crowdfunding the development of a board game or developing a digital app for a thematic city tour. Direct book sales (upon request with a personal dedication from the author) are complemented by the sale of products referring to them (e.g. a board game, calendars, figurines, guide books to Kraków). The shop is also the main physical base for guided tours to Kraków's historic sites offered by the writer.

Wollny's strategy is a combination of presence in the very city centre (the shop is next to Kraków's main parish Church of Virgin Mary and Main Square) and on-line. His motivation to start his two own businesses was to have additional income from thematically linked, writing-related activities. With time, however, the wish to fully control all stages of book production, from the original concept of a book through production to distribution, became equally important. The writer wants to make sure that profits from his creative endeavours are not taken over by intermediaries.
The location in the very city centre allows him not only to have direct contact with readers or organise book promotion activities, but also enables him to offer additional services to capture incidental customers and new potential readers who are tourists to Kraków. He therefore sees it as complementary to on-line activities (most of his books are now sold on-line) and activities outside Kraków such as authors' meetings. He finds buyers not only thanks to good location but most of all thanks to the attractiveness of Kraków as the major Polish historic city, its nostalgic historic image and the large number of tourists who visit it. The choice of location is also linked with specific rental conditions. He would not be able to afford market level rent, therefore the shop space is rented from a major municipal institution engaged in the preservation and promotion of Kraków's heritage - the Historical Museum of Kraków in one of its branch buildings. Wollny's shop may thus function as a quasi-museum shop and benefit from preferential rent as an activity in line with the museum profile. This compensates for some drawbacks of the location such as the lack of direct entry to the shop from the street level. Another advantage on the city level is the fact that the development of Wollny's business coincided with Kraków receiving the prestigious title of the UNESCO City of Literature (2013) and intensification of promotion of the city in this context. Park benches devoted to particular writers with QR codes, including Wollny, in the Planty park surrounding the Old Town are a good example of it. The location is linked with two main factors: professional links with cultural institutions and access to tourists who are potential customers. The issue of socialising with other artists or proximity to them is not important for this artistic enterprise. This type of entrepreneurial activity reinforces the nostalgic image of Kraków as a 'magic' historic city. It draws on and supports the tourist orientation of the city centre as the quarter of artistic memory and traditions.

Case study 2: Educated as a graphic artist, photographer and designer, Magdalena Maślerz has always been interested in the design and handmade production of artistic jewellery. She has also been aware of the challenges and trends in the artistic and alternative jewellery market as well as the need for practical jewellers' education. 
Following graduation in an arts major, she was able to gain practical experience working in an atelier of a traditional master jeweller. Skills and knowledge obtained there allowed her to pass both apprentice (2013) and master level (2016) official goldsmith exams and obtain the title of the goldsmith as one of the youngest and one of the few female representatives of this craft in Poland.

The jewellery market in Poland has undergone substantial transformations in the last three decades. The traditional system of training goldsmiths based on centuries-long traditions of apprenticeship under the supervision of older craftsmen has collapsed after 1989. Customers are prone to choose mass-made, industrially produced jewellery offered by a few well-known large firms. Independent jewellers have to struggle both to compete with mass-made products in terms of prices and to follow changing fashions. Thus, although the volume and value of jewellery sold in Poland constantly grows, this benefits only major players and mass production while the number of smaller jewellery shops constantly decreases. The audience for artistic jewellery is limited, hence both options of setting up a permanent shop and of periodic sales at art or jewellery fairs do not guarantee a stable income. At the same time often very imaginative ideas of young artists who would like to design jewellery cannot be implemented as they lack practical skills for actual jewellery production. Maślerz was thus conscious that she is unlikely to make a living by making artistic jewellery alone. She decided to diversify her activities linked with traditional jewellery taking three directions: avant-garde artistic activities - specialising in artistic jewellery made from animal bones exhibited at art shows, custom-made jewellery catering to the needs of particular clients and establishing a jewellers' school to fill the void in practical goldsmiths' education opportunities. Her school 'Xerion', founded in 2013, was the first in Kraków, and among the few in Poland, to offer professional goldsmith courses and teaching traditional handmade techniques within the framework of structured, longer, professional courses or on more ad hoc basis (e.g. wedding ring making programmes for engaged couples).

Her artistic offer is promoted mainly by wordof-mouth recommendations, at specialist events and on-line. The firm is based in the heart of the
Old Town in a historic tenement from 1900 not far from the assay office and other, older jewellers. It is on a less frequented side street, however, in the eastern part of the Old Town and it rents rooms without a storefront visible to passers-by and does not boast a noticeable signboard. Thus, the location is both in line with a specific character of the particular trade (i.e. the image of prestige, dependability, traditionalism, references to centuries-long traditions of making and selling handmade objects of precious or semiprecious, fine materials), yet it is inconspicuous, as it is not dependent on nor counts on incidental customers. The location is much appreciated by the artist, but this is neither linked with proximity to her place of living (in a suburban location) nor professional socialising and networking opportunities, though she enjoys easy access to some leisure possibilities in the area. The practical aspects of this location connected to the closeness of the train station and municipal transport as well as the wish to separate private life from professional commitments are strongly stressed by her. Although the artist is aware of the existence of other jewellers in the broadly understood historic centre and is also a member of a relevant guild, this does not translate into frequent uses of the physical proximity in urban space for professional networking. Her personal web of professional relations is more dispersed in the city and includes artistic photographers and makeup artists, cultural centres and other organisers of artistic and cultural events such as jewellery fairs and competitions not necessarily located in the city centre nor linked with visual arts and design.

The entrepreneurial activity of Maślerz is successful thanks to finding a niche in the education market at the intersection of artistic and craft activities allowing her to diversify income sources. It benefits from the growing interest of younger generations in traditional handmade techniques often as a pleasurable leisure time and a hobby. The presence of her firm in the city centre of Kraków, contingent upon moderate rent rates, on a side street and on the ground floor of a slightly dilapidated building without possibilities of having a visible showcase is conducive to the maintenance of historic, non-tourism oriented production and artistic functions of the city centre, drawing to some extent on its historic atmosphere, but having no links with dominant 
controversial touristification processes in the area. Such processes, if they continue to intensify, might push Xerion to move out from the current premises to a different location, should the artist want to upgrade or enlarge its seat or should the building owners decide to substantially renovate it.

\section{An artistic firm in a historic downtown area without a clear artistic image}

Case study 3: Anna Kaszuba-Dębska is a multidisciplinary artist: a painter, a graphic designer and a book illustrator, an author and a director of cartoon and advertisement projects, an interior designer and a writer. She is a graduate of the Academy of Fine Arts in Kraków (painting and multimedia arts) and holds a PhD from the Academy of Fine Arts in Warsaw. One of key areas of her academic and artistic interest are avant-garde 20th century artists such as Bruno Schulz or Tadeusz Kantor. Her passions are shared by her husband Łukasz Dębski, a journalist, a poet and a writer. Both of them are engaged in diverse interdisciplinary artistic and educational projects, including writing children's books and stories and running a foundation focused on promotion of reading among children. They are very passionate about their work but also very pragmatic about it, aware of the need to tap into different sources of financial support for artistic projects (grants, stipends, commercial assignments, prizes, running creative workshops) and possibilities of cooperation, e.g. with the local municipality and municipal cultural institutions and other organisations or working on-line for clients from Warsaw. Having finished artistic studies, they wanted to continue artistic activities but also diversify their sources of income. In 2002 they created an artistic café - Café Szafé with a rich programme of cultural happenings, meetings and events. Its purpose is not only to provide additional income for the owners but also to give them opportunities to implement artistic ideas, meet other people, get inspired ${ }^{1}$ and promote or sell the outcomes of their creative activities.

As it was not their key intention to be nearby other artists, the couple spotted the opportunity

Dębski has even published a book based on his experience of being a barman at the café. to rent some space on the ground floor of a historic tenement house west of the Old Town (Nowy Świat). At the same time they purchased a house located slightly further away from the city centre, in the same direction and use it both as their home and work-place. The live-work option allows them to create in peace and quiet and save on paying rent for a separate atelier. In turn the café offers them an opportunity to socialise with other people, not necessarily artists representing the same discipline, when they need a break from solitary creative work at home. Café rooms with interiors designed by Kaszuba-Dębska and furnished with old wardrobes and artefacts she collected and painted do not only serve a catering function but are a very frequent space for concerts, workshops, lectures, travellers' slide shows, poetry meetings, film shows and exhibitions. They comply with expectations of a place with a bohemian atmosphere, a fact noticed by filmmakers (e.g. depicted in the film 'Pod Mocnym Aniołem'). The café is in a quieter 19th century, historic residential area, without an artistic image or major tourist attractions. Its regulars are more likely to be local residents, art students or longer term expatriates, making it more 'authentic' and 'local', though at the same time running it is less attractive from an economic point of view. In the face of growing tourism traffic and change of balance between commercial and artistic activities in the main areas of tourism and night life in Kraków (Old Town, Kazimierz), the firm represents an artistic entrepreneurship model of more symbiosis and balance between economic and cultural focus, which might not be fully satisfactory in economic terms but is very rewarding in artistic terms confirming dispersion of more 'genuine' artistic social life away from the city centre.

\section{Artists operating in an area considered the key independent artistic quarter of Kraków}

Case study 4: Slow Fashion Café opened in 2012 as a brainchild of two young fashion designers Monika Szumińska-Nemeth and Katarzyna Stypulska-Trybulec. As graduates of Cracow School of Art and Fashion Design, they wanted to continue designing yet were also aware that alternative fashion does not usually generate enough income to make a living. One of them had some 
practical experience of working as a designer for an alternative jewellery firm in Kraków and she also had some ideas to develop a pregnancy clothing line - the probability of success of such a venture was however very low. The two partners therefore wanted to come up with a more feasible formula of artistic and business oriented activity. Ultimately, they decided to refer to the growing popularity of 'slow life' movements and the growing interest in the hand-making of clothing as a hobby, a way to spend leisure time and derive satisfaction from learning manual tasks among the (metropolitan) middle classes.

At first, their fashion atelier and workshop opened relatively close to the city centre but in a modern apartment building, on a hardly visible side street behind the hotel complex on the right bank of the Vistula river, opposite the Old Town. Working with the first clients made them conscious of the need to relocate to an area more perceived as linked with art and design and the requirement to have a visible shop window. One of the designers actually had the experience of living in Kazimierz and although she did not particularly appreciate it as a residential area, she knew very well its qualities and image as an artistic quarter. Therefore, when an opportunity to rent space on the ground floor of a historic tenement house in Bożego Ciała street in Kazimierz arose, they accepted higher rent in return for better visibility and easier access to different potential customers both as participants of sewing and design courses and buyers of clothing. Their main target group was the residents of Kraków, in particular young women who were searching for an opportunity to relax from maternal and household duties in a nice atmosphere, persons who were interested in developing manual skills and singles looking for the possibility of doing something outside their routine professional tasks in non-creative enterprises. Kazimierz is also a major area of tourism traffic in Kraków. Tourists rarely join sewing courses, but drop by the café and buy originally designed clothing.

Although numerous alternative fashion and design shops present in Kazimierz do not cooperate with each other on daily basis, they are none the less aware of being a part of one, larger creative ecosystem. On the city level, the two business partners also cooperate with artists who may offer goods and services complementary to their activities: visual artists, photographers and filmmakers, musicians, fashion stylists, alternative jewellery and fashion accessories makers. The firm is also engaged in numerous connections and links with the broader Kraków fashion milieu and participates in various initiatives promoting fashion such as the Kraków Fashion Week.

Slow Fashion Café is another example of hybridity of artists' firms allowing for the diversification of artists' income sources in the face of limited economic potential of main artistic activity. The historic landscape and setting of artistic quarters make such activities more visible and make them appear more genuine. The location in an artistic quarter is an integral part of a conscious strategy which makes their economic activities feasible, but at the same time reinforces the functional orientation and image of already existing clusters of artistic and creative activities within the city.

Case study 5: Renata Loj is a self-taught visual artist producing fairy tale-like graphics, mainly in the form of small drawings, sometimes also of decorative objects such as painted stones or keys. Her artistic creation evolved gradually from a hobby into a way of making a living. Encouraged by her husband, she first began to participate in amateur shows, then in alternative design events and started to sell her artworks in the open air market in Kazimierz. These experiences allowed her to gain some practical knowledge on how the market for the specific type of artworks, often bought for interior decoration, as a charming gift for children and friends, works. As her artworks are also well inscribed in the atmosphere of the informal, avant-garde quarter, in 2013 she decided to establish a permanent Lookarna Illustrations Shop and Studio. Her seat combines the function of an artistic atelier and a shop. The possibility of meeting and watching the artist at work serves as an additional encouragement to buy her artworks, but also minimises the costs of the artworks' distribution. Her artworks are unique, handmade objects which are none the less not too expensive for making a quick decision while on a tourist trip or on a leisure walk. The economic feasibility of this venture is greater because of the fact that the premises are small, rented in a still not renovated, historic building where a lot of similar functions cluster, on the 
main 'artistic' walking axis of Kazimierz (Józefa street), frequented both by locals and by tourists and well-known for small galleries, cafés, vintage and design shops. The artist is happy to distinguish between private, home space (outside Kazimierz) and atelier space and be able to directly promote and sell her art bypassing any possible intermediaries. As this strategy requires visibility, the artist has decided to attract attention by creating an original mural painting with motives characteristic of the artist's style on the walls next to the shop entrance.

In this case there is a strong symbiosis of image and functions between the artistic firm and its setting. The artist benefits from the image of this part of Kraków, while the quarter's image is enhanced by her creative presence. Such atelier-shops help Kazimierz to maintain its artistic aura though their long term presence in the area cannot be taken as a given as growing tourism and investment pressure on redeveloping historic buildings for more profitable activities (e.g. hotel functions) might endanger both the artistic status of the area and the possibility of running such firms.

Case study 6: Piotr Kaliński is a professional visual artist (an engraver and an illustrator) who has been engaged in entrepreneurial activities since the very beginning of his artistic career both to generate income and to implement some of his artistic ideas (Niemczyńska 2014). His first undertaking was to open an internet café in the Old Town in the late 1990s. It was not only successful in business terms but also became a meeting point for young students of Polish literature and other artistic types. When Kaliński noticed that internet cafés are declining in popularity, he decided to open another venue. He wanted to run an art gallery but was aware that inclusion of a café function will make this idea economically viable. Lokator (the Tenant) club opened in 2001 in an old outbuilding next to one of the major streets of Kazimierz (Krakowska). The new spot started to attract a very artistic crowd of poets and writers, with its own art-zin, numerous meetings and performances. It quickly became a significant literary hub, artistic and night life place frequented by most promising young writers in Kraków. In 2006 the already well-known club moved across the street to a much larger, more visible venue on the ground floor of the
Nuremberg Cultural House. Its activities broadened to include exhibitions, film shows, literary meetings, concerts and selling books in addition to publishing an arts magazine with Kaliński as its editor-in-chief. Lokator also started to publish books of avant-garde, experimental Polish and foreign authors.

In 2011 its owner decided that he would like to change the club's formula again. He wanted to continue publishing activities, but be able to concentrate more on his own artistic work and family life. He reopened Lokator this time as a café-bookshop and publishing house combined with gallery activities (Atelier PIO) at a new, less central address in Mostowa street. The new location, however, was also strategic as although this part of Kazimierz is regarded as more quiet and peripheral, the particular street leads to a new pedestrian bridge opened in 2010, making it a likely strolling direction for many people walking from the Old Town and Kazimierz towards Podgórze. The place is thus both accessible to people familiar with it and, thanks to a large shop window, noticeable by casual passers-by. Its atmosphere, however, is far from the original, rather shabby and run down climate of the first Lokator, and the type of aura traditionally associated with Kazimierz and its cafés of the artsy or nostalgic Jewish type. The building's façade is clean and freshly renovated, the café-book shop interior is bright and modern in style. As such it might appeal more to residents of Kraków than to tourists looking for signs confirming the artistic and picturesque status of Kazimierz. Lokator is also a reflection of a broader new model of a café-book shop that has emerged in recent years in response to new trends in the book market as the only (or one of the key) economically feasible strategies for contemporary independent bookshops, taking into account dominance of major chains, the preponderance of on-line sales and digital book consumption.

The artist is strongly embedded in the networks of artistic cooperation with both visual artists and the literary circles. The current entrepreneurial formula allows him to diversify income while achieving some artistic and cultural aims (promotion of own artistic endeavours, as well as ambitious poetry and prose). This example also shows that artistic entrepreneurial activity might evolve following changes in a particular creative 
sector (e.g. the book market), generational and life cycle changes and transformations taking place in the space of particular quarters (in this case greater commercialisation of major streets of Kazimierz and new opportunities linked with the construction of the pedestrian connection to Podgórze). To some extent it fits the typology of Cunningham and Tollonen (2019), whereby the artist engages in his own artistic work, but seems to take on another role of being an intermediary, important for the promotion of the artistic oeuvre of others. Kaliński has indeed fulfilled this role for many years, though as visible in his recent entrepreneurial decisions, he has finally decided to focus more on his own artistic work.

\section{Artistic entrepreneurship in emergent and potential artistic quarters}

Case study 7: Drewniano.com is an artistic workshop engaged in the design and production of original, custom-made furniture, using natural materials, such as highest quality wood, as well as experimenting with diverse techniques and less common materials, responding to unusual demands of clients. Its founder Szymon Bielecki has become fascinated with wood, its beauty and irregularity, learning carpentry and handiwork from his father. At a young age, he started to work as a camera operator for a TV station, then undertook formal university studies in film and TV production at the reputed Lodz Film School. For a long time he was focused on professional activities linked with TV and film making. From his perspective, the Kraków film and TV cluster has been suffering from a marked decline and the number of film commissions dropped significantly, while at the same time competition for them increased due to technological changes and lower entrance barriers. He therefore had to search for other, complementary sources of income. Meanwhile, the earlier intensive involvement in film and TV production which from time to time required retreating to the quiet of other, less demanding activities inspired him to get involved in furniture making. He started it initially as a hobby, renting a barn nearby Kraków to relax and fulfil his personal and his friends' needs for unique, high quality furniture. The original, simple designs exploiting the aesthetic qualities of natural wood captured the attention of commercial clients. At the same time, thinking of his own professional film studio, he searched for a place relatively nearby his place of residence and found a disused warehouse in Józefińska street in Old Podgórze. The site was eventually turned into a furniture design and carpentry shop. It allowed him to diversify and stabilise his income and with time proved much more rewarding and less demanding than film and TV-related work. He is still to some extent engaged in it, but furniture making is now his main focus. He is well aware that the prosperity of his firm is to a great extent linked with his skills and ability to find a niche in the furniture market, visible especially in larger metropolitan urban centres, where there is demand for upscale, high quality, original furniture, expressed especially by some creative firms. Traditional carpenters lack original ideas though might have necessary manual skills and technological know-how. In turn young designers might have proper artistic backgrounds, but have no practical skills, are often afraid of technological experimentation or tend to repeat ideas taken from elsewhere.

Although the firm has a web page, it gets most of its commissions thanks to word-of-mouth recommendations. It caters mainly to the needs of firms in non-artistic branches of the creative sector such as IT firms as well as furnishes trendy bars, cafés and restaurants. As all of its production is custom-made, it is also a supplier of props and stage sets for avant-garde theatre plays, film productions or specific upscale interior designs. Although some of its customers are from Kraków, including the nearby quarters, commissions are obtained from all over Poland.

The firm was based in a former warehouse rented from private co-owners who recently decided to sell it to a developer. As he intends to demolish the existing structure and build an apartment house in their place, in the early 2019 the firm had to relocate from the heart of Old Podgórze to a newer and more peripheral area in its outskirts. This has not changed the firm's situation significantly as it does not depend on being directly visible to its potential clients, having a proper showroom or networking with nearest creative firms. The best showcase for the firm are trendy, artistic or IT-related spaces where new potential clients see the furniture as it is used and admired. It is, however, reflective of difficulties experienced 
by culturepreneurs in Kraków and their likely displacement from more centrally located areas due to investment pressure. In addition, the mural-like façade of the building Drewniano.com was based in with clear references to the firm's activities, contributed much to the look and feel of the street as an artistic and alternative creative space. Its profile was also complementary to that of artistic establishments nearby, the more recent experimental book shop-gallery Księgarnia Wystawa and the older Ossolin Art specialising in gilding and renovation of wooden objects and artworks. Bielecki exchanged information with its owners as well as enjoyed the possibility of socialising with them, though their co-presence had no direct impact on his activities. As a local resident, he appreciates this particular area for its atmosphere and 'little town' charm. He therefore finds that more public support should be given to encourage creative firms such as his to remain in the area and sustain its reputation, more to the benefit of the quarter than to a particular firm.

Case study 8: Agnieszka Wojtuń is a university graduate with a degree in humanities and a selftaught artist (a photographer) who first worked for someone else's photo studio, then decided to establish her own firm: Green Carrot Multimedia Agency. Her strategy was first to combine engagement in commercial photography (fashion, luxury goods and food photography) as the main source of income with non-commercial, independent artistic projects as a way of 'efficient' use of time between commercial assignments. In 2013, in a partnership, she opened a larger, professional studio surface (Studio Zabłocie) to further diversify her income, become more flexible and competitive in terms of organising own photography sessions and renting it to other parties for creative (making films and commercials) and non-artistic events.

As she works for a variety of clients (e.g. major and independent fashion and apparel firms, women's magazines, shopping centres, banks, cosmetics and household equipment producers, book publishers) outside Kraków or based in different parts of the city, her firm does not have to be directly visible in urban space. Her choice to rent rooms in a post-industrial building of the former Unitra-Telpod electronic components company in the Zabłocie district was at the start linked with relatively low prices, flexibility of adaptation of interiors, adequate working conditions (i.e. welllit rooms) and proximity to her place of residence. With time, two factors contributed to her stronger attachment to the area and the choice to remain in it, first to move to larger premises on the top floor of the same building (now transformed into luxury student apartments) and then to relocate to another part of the quarter. She spotted the possibility of using references to Zabłocie and its space as a distinguishing label, indirectly referring to the image of the quarter as a post-industrial space where interesting, avant-garde ideas might be conceived. Work in Zabłocie helped her to establish links with various artists and firms in the area, especially these connected with film and photography (e.g. LabLab, Luma, Foundation for Visual Arts) and other similar firms in Kraków (i.e. the House of Retouching). The firm's current seat is a part of an organically developed creative cluster focused on photography which emerged in a back lane behind the Museum of Contemporary Art in Kraków. Apart from photo firms and visual artists, it comprises Zabłocie's main artistic bar (Bal) and its well-known multidisciplinary co-working space (Wytwórnia). In addition, Wojtun has also been cooperating with some museums in Kraków and bottom-up local cultural initiatives such as the Polikultura festival organised by university students. She has also done photo sessions for local independent fashion labels. As a pragmatic, artistic businesswoman she understands that cooperating and fostering links between different firms in the creative sector might be inspiring and useful to all of them as such firms get commissions mainly thanks to word-of-mouth recommendations from other creative firms and satisfied customers, though not necessarily linked with a co-location in a specific quarter. At the same time, she is aware that the local cooperation networks are very fragile, as the ongoing transformation of the area into a densely built-up luxury apartments and office zone might in the end lead to the disappearance of still existing pockets of creativity within it and their ultimate relocation elsewhere. Persons, places and changes taking place in the quarter have in fact become the subject of her photographic recording and even led to an exhibition focused on the issue.

Green Carrot and Studio Zabłocie are again an example of a hybrid artistic entrepreneurship 
which is embedded in the larger creative scene of the city. Although due to the specialist nature of its services the firm is promoted mainly by wordof-mouth and does not need to be visible in urban space nor accessible to the general public, it might, none the less, with time, become more closely connected with a quarter where similar activities co-locate, both use and contribute to the artistic reputation of an area. The long-term sustainability of such a cluster is however doubtful due to the pressure of non-creative actors, developers and investors - making it an ephemeral case of an artistic quarter which image is used both by artistic firms and by developers who are ultimately likely to replace them.

\section{Virtual visibility and location of entrepreneurial activities outside recognised or promising artistic areas}

Case study 9: Ewa Kociuba is a visual artist and an art conservator who graduated from the Academy of Fine Arts in Kraków. Born in the south-eastern corner of Poland with significant multicultural traditions, linked with the presence of Eastern Orthodox and Greek Catholic minorities and their art, she is able to both have an insider's understanding of such works of art and produce their replicas or her own original interpretations of religious themes. Her atelier Tempera Workshop specialises in the 'writing' of Eastern Orthodox icons and copies of Western European Medieval and Early Modern works of art. Paintings are produced for particular buyers upon request either following a customer's idea for a copy of a specific work of art or a certain style.

Kociuba has found a specific niche in the art market. In Poland, there is still a sizeable demand for copies of best known religious works of art or paintings of well-known masters expressed by persons who do not necessarily frequently visit art galleries or antique shops. She also wanted to be more economically independent in her artistic work and avoid using intermediaries such as art galleries. She decided to concentrate on on-line promotion and sales, using the possibility of logistic and technical support of her husband. Her entrepreneurial strategy also includes the overlapping location of the place of residence and artistic work as private spaces without direct contact with customers. Thus, the seat of her firm is located in the attic of the same block of flats as her private apartment in one of the housing estates from communist times in the Nowa Huta district of Kraków at a distance from the historic city centre and not in the centre of this newer, more peripheral quarter. The workshop is not visible to the general public and its urban setting does not have any artistic attributes nor image. The location was selected for family reasons as affordable and offering desired amenities for families with children, an important factor because of the live-work strategy followed by the artist.

Kociuba's artworks are unlikely to attract the interest of 'usual' tourist or hipster visitors to artistic quarters anyhow. A workshop based in a more artistic area would therefore be more costly to rent but very unlikely to impact positively on reaching a broader audience. In addition, the artistic atelier in this particular location fulfils important technical requirements in terms of access to light, running water and good ventilation, offers peace and quiet necessary for artistic creation. This type of artistic genre makes traditional artistic networks less useful in accessing information and obtaining commissions, too. The artist is appreciative of the dispersed artistic milieu of Nowa Huta and its recent developments and she enjoys friendly relations with some artists in the area, but more for social rather than professional reasons.

Case study 10: Trained as an architect and an urban planner, Marek Sietko Sierkiewicz has gained experience in running a firm while working for a family jewellery shop and in architectural offices. Finding both jobs monotonous and not particularly personally satisfying, he decided to develop his own ideas for furniture design, in particular lamps, creating his own lamp brand Brasto. His experiments with forms and shapes, using every-day objects and wood pieces resulted in the development of a unique line of sculpture-like lamps with playful references to forests, forestry and lumberjacks' work. Such household objects find customers mainly among large city dwellers searching for original home furnishings.

His lamp design firm is for now mainly the vehicle for implementation of own design ideas with all profits reinvested in further development and commercialisation of designs rather 
than a stable source of income. The location of his workshop is therefore mainly linked with financial and family considerations and the enterprise is not visible in urban space at all. He lives in a historic early 20th century quarter nearby the city centre (inherited from a family member), but designs and produces his handmade lamps in a suburban village north-west of Kraków in his family house where he can use rooms free of charge. For now his unique lamps are either sold in selected designer shops, mainly outside Kraków, a shop with Polish design in Berlin serving as his main intermediary, or custom-produced for particular persons. If the firm expands however, he is likely to consider relocating to the city centre and combine an atelier and a gallery function taking into account that many clients are more likely to purchase rather expensive, avant-garde design objects if they can check their quality personally rather than see them on-line. Having a publicly accessible, more centrally located workshop would thus be connected not so much with finding a more comfortable workspace but with hopes for access to new clients in places where such establishments cluster (e.g. in Old Podgórze), though Sietkiewicz is also aware of their high rate of rotation and failure.

According to him, one can search for inspiration for original design ideas anywhere, nowadays mainly on-line or in any type of surroundings. This is not that he does not appreciate the possibility of gaining experience and knowledge through direct face-to-face contacts with other creatives but rather that recent technological changes enable artists to be more autonomous in deciding when, with what frequency, and in what form such contacts may take place. He notices that such encounters are usually most needed and useful at a certain, especially early, stages of a firm's development and could become counterproductive in the long run. In his case while developing early project ideas for his firm, he frequented the artistic co-working space of Wytwórnia in Zabłocie. He went there not so much with hopes to get inspired and come up with original artistic ideas, but rather to gain practical knowledge and observe how he can commercialise them, how to deal with clients and avoid traps linked with implementation of artistic ideas as a commercial project. After a few months the place served its purpose and he no longer needs to make use of it on regular basis.

\section{Conclusions}

Artists undertake entrepreneurial activities for many reasons. First of all they might want to sell the outcomes of their creative efforts directly because their customers express the desire to physically see a product or the process of its creation before making a purchase to ascertain its quality, gain a greater appreciation of its uniqueness and authenticity or because the artists want to by-pass intermediaries, their fees and surcharges retaining more profits from sales. Having an own firm might also be seen as a more effective way of self-promotion of a particular artist or an opportunity of engaging in direct contacts with audiences even if the artistic discipline as such does not make them necessary. The desire to be more independent and autonomous in shaping one's artistic or design career in more commercially oriented artistic fields such as photography or interior design is also a potential motivation. Establishing an artistic firm is very frequently linked with the need to diversify sources of income from artistic activities or broadening the range of artistic activities switching from those which no longer bring satisfying income to more promising ones or ensuring more stable, regular income (Oakley 2014). Running an own firm might also be connected with the wish to obtain supplementary, additional income from providing restaurant and café services, teaching artistic skills or selling thematically linked goods and services (Leadbeater, Oakley 1999). Finally, such a firm might provide an artist with possibilities of fostering professional and social links outside more private, residential spaces or inward directed, creation focused ateliers as inspiration and diversion from the solitude of individual creative efforts or as an artistic experiment and a possibility of implementing original artistic ideas.

Fulfilling the above aims, artists might follow diverse entrepreneurial strategies or a combination of them such as:

1) opting for a focus on artistic production (sales of creative goods taking place away from the site of their creation, directly on-line or using intermediaries);

2) combining the place of artistic creation (an atelier function) with direct sales of its outcomes (a gallery function); 
3. combining artistic production with education and workshop functions;

4. making the firm's venue serve a triple function of an atelier, a workshop space and a café;

5. linking the production, display or sale of own artistic goods with the sale of creative goods produced by others;

6. creation and sale of a broad range of products and services on the basis of the core creative activity.

Particular entrepreneurial strategies translate into location strategies of artists' firms and their visibility in urban space. Presence and pronounced visibility to passers-by in the physical space of an artistic quarter is one of the options selected more often if the artist decides to sell the outcomes of his creative efforts directly or engage in artistic education and workshop related activities (Table 1). A particular location is then selected taking into consideration the ease of access to the desired or expected type of customers (cf. Heebels, van Aalst 2010; Rius Ulldemolins 2012) - with the dominance of local residents and residents of the city as such or temporary visitors to it (tourists). The other option is presence in a recognised artistic quarter but relative invisibility to the general public either because of the focus on artistic production or because of rather exclusive, specialised type of the workshop offer. A diametrically opposite strategy is opting for a location in a non-artistic quarter (i.e. an area not perceived as such) and not being particularly visible in it, either making use of artistic intermediaries or virtual promotion and sale possibilities to reach potential audiences. Thanks to technological changes in particular art markets (i.e. digital revolution) artists can also be successful culturpreneurs in more every day, peripheral locations (cf. Hracs 2009). The issue of catering to more local or more non-local audiences is also of importance.

Contrary to expectations, not all artistic entrepreneurs need nor desire to locate in recognised artistic quarters. Moreover, artists' firms presence in an artistic quarter might also be linked with overlapping non-artistic family and economic considerations, not with particular entrepreneurial strategies and be contingent upon real estate ownership in a certain area or possibility of its inexpensive rental or proximity to the place of residence appreciated for family reasons.
Opportunities for local artistic networking and frequent encounters with other artists are not the most important location factors considered by most artists who run micro-firms in Kraków and are of secondary importance in comparison to more practical, pragmatic considerations such as rent levels or access to desired customer segments (cf. Heebels, van Aalst 2010). Longevity in the challenging market for creative goods and services in the long term is rather linked with access to broader networks on the city or (inter) national level, not at the neighbourhood level (cf. Heebels, van Aalst 2010), even if with time a particular quarter may indeed become a part of a given artistic entrepreneur's or firm's professional identity (Rius Ulldemolins 2012).

Thus, only few artists directly impact on the artistic functions and image of artistic quarters, by running artistic enterprises clearly visible in urban space and accessible to the general public such as art galleries, artistic cafés, bookshops and workshops or hybrid places. 'Mature' cultural quarters are therefore to a larger extent the space, where artistic micro-firms focused on direct sales or consumption of outcomes of creative efforts tend to locate rather than firms focused on artistic production. This echoes the proposed lifecycle of artistic quarters and their transformation from emerging to mature artistic quarters and the related change of focus from production and avant-garde artistic activities to artistic activities linked with a broad offer of artistic workshops, sales and consumption of art, including sales of applied art objects and tourism services (Debroux 2013; Działek, Murzyn-Kupisz 2014). Only those artists for whom visibility and proximity to potential clients is indispensable are likely to opt for mature artistic quarters, especially taking into account higher rental prices there. Additional factors modifying the above mentioned entrepreneurial strategies of artists are the development stage of a given artistic firm, its focus on incidental or specialised, local or non-local customers, its decisions with respect to making use of artistic intermediaries or avoiding them, the importance and intensity of presence in virtual space as well as family and ownership considerations (ownership and accessibility of attractive rental offers of usable space).

The researched enterprises have been in the market for at least five years already, which may 
be considered a relative success in the context of the creative sector and may be partly attributed to well-thought-out economic and spatial strategies adapted to market needs and opportunities. Their sustained existence is also a reflection of the

general good prospects of the city in the second decade of the 21st century, among others linked with the dynamic development of the outsourcing sector, growth of the high tech and IT sector, the emergence of new metropolitan middle class

Table 1. Locations of artistic firms and their advantages in the context of economic and spatial strategies followed by particular artistic entrepreneurs in Kraków.

\begin{tabular}{|c|c|c|c|c|}
\hline $\begin{array}{l}\text { Physical location in a spe- } \\
\text { cific area or quarter type }\end{array}$ & $\begin{array}{l}\text { Potential advantages in the context } \\
\text { of a particular economic and spatial } \\
\text { strategy }\end{array}$ & $\begin{array}{c}\text { Desired } \\
\text { visibility in } \\
\text { urban space }\end{array}$ & $\begin{array}{l}\text { Targeted customer } \\
\text { types (segments) }\end{array}$ & Case study \\
\hline \multirow{2}{*}{$\begin{array}{l}\text { inner city area - a historic } \\
\text { quarter of artistic memory } \\
\text { and traditions, dominated } \\
\text { by tourism, with major } \\
\text { public cultural institutions, } \\
\text { niches of less commercial } \\
\text { and independent cultural } \\
\text { activities (Old Town) }\end{array}$} & \multirow{2}{*}{$\begin{array}{l}\text { - proximity to large flows of local } \\
\text { and non-local customers and major } \\
\text { transport hubs; } \\
\text { - direct face-to-face contacts with } \\
\text { customers; } \\
\text { - possibility to use the image of } \\
\text { tradition and prestige of cultural } \\
\text { heritage and cultural institutions. }\end{array}$} & $\begin{array}{l}\text { high or rela- } \\
\text { tively high }\end{array}$ & $\begin{array}{l}\text { Polish tourists, to } \\
\text { some extent for- } \\
\text { eign tourists and } \\
\text { residents of other } \\
\text { parts of Kraków }\end{array}$ & $\begin{array}{l}\text { Kacper Ryx } \\
\text { Historical } \\
\text { Shop } \\
(1)\end{array}$ \\
\hline & & low & $\begin{array}{l}\text { local and non-lo- } \\
\text { cal longer term } \\
\text { participants of } \\
\text { workshops, regular } \\
\text { clients }\end{array}$ & $\begin{array}{l}\text { Xerion } \\
(2)\end{array}$ \\
\hline $\begin{array}{l}\text { prestigious historic area on } \\
\text { the edge of the inner city } \\
\text { - a quarter of tacit artistic } \\
\text { production and residence } \\
\text { without a clear artistic } \\
\text { image (Nowy Świat) }\end{array}$ & $\begin{array}{l}\text { - finding a niche in terms of drawing } \\
\text { regular, more local customers tired } \\
\text { of buzz and overtourism of other } \\
\text { historic areas; } \\
\text { - possibility to refer to the area's } \\
\text { historic yet 'laid-back' image. }\end{array}$ & moderate & $\begin{array}{l}\text { local, regular cus- } \\
\text { tomers, students }\end{array}$ & $\begin{array}{l}\text { Café Szafé } \\
(3)\end{array}$ \\
\hline \multirow{3}{*}{$\begin{array}{l}\text { less prestigious historic } \\
\text { area on the edge of the } \\
\text { inner city undergoing } \\
\text { dynamic regeneration } \\
\text { - a quarter popularly } \\
\text { recognised as an artistic } \\
\text { area with the dominance } \\
\text { of independent artistic } \\
\text { activities and nightlife } \\
\text { (Kazimierz) }\end{array}$} & \multirow{3}{*}{$\begin{array}{l}\text { - proximity to local and non-local } \\
\text { customers representing specif- } \\
\text { ic, promising market segments } \\
\text { (younger and middle age local con- } \\
\text { sumers with cultural aspirations, } \\
\text { independent, cultural tourists); } \\
\text { - proximity of other creatives and } \\
\text { culturpreneurs; } \\
\text { - possibility to refer to the area's } \\
\text { artisanal traditions and use its alter- } \\
\text { native, 'authentic' image to 'certify' } \\
\text { the uniqueness of the firm's offer. }\end{array}$} & \multirow[t]{3}{*}{$\begin{array}{l}\text { high or rela- } \\
\text { tively high }\end{array}$} & $\begin{array}{l}\text { local customers, } \\
\text { participants of } \\
\text { workshops, to } \\
\text { some extent tour- } \\
\text { ists }\end{array}$ & $\begin{array}{l}\text { Slow Fash- } \\
\text { ion Café } \\
(4)\end{array}$ \\
\hline & & & $\begin{array}{l}\text { more culture-ori- } \\
\text { ented, independent } \\
\text { tourists, Polish and } \\
\text { foreign, to some } \\
\text { extent residents } \\
\text { of other parts of } \\
\text { Kraków } \\
\end{array}$ & $\begin{array}{l}\text { Lookarna } \\
(5)\end{array}$ \\
\hline & & & $\begin{array}{l}\text { local clients, resi- } \\
\text { dents of other parts } \\
\text { of Kraków, to some } \\
\text { extent tourists }\end{array}$ & $\begin{array}{l}\text { Lokator - } \\
\text { Atelier PIO } \\
(6)\end{array}$ \\
\hline $\begin{array}{l}\text { former working class/ } \\
\text { industrial area nearby } \\
\text { the inner city - an area } \\
\text { considered as an emer- } \\
\text { gent or temporary artistic } \\
\text { quarter (Old Podgórze and } \\
\text { Zabłocie) }\end{array}$ & $\begin{array}{l}\text { - adaptable, larger, post-industrial } \\
\text { surfaces; } \\
\text { - relative proximity to the city centre; } \\
\text { - possibility to refer to the area's } \\
\text { artisanal traditions and use its alter- } \\
\text { native, 'authentic' image to 'certify' } \\
\text { the uniqueness of the firm's offer; } \\
\text { - peace and quiet for artistic creation. }\end{array}$ & \multirow[t]{2}{*}{$\begin{array}{l}\text { lack of } \\
\text { visibility, } \\
\text { no need } \\
\text { for a more } \\
\text { pronounced } \\
\text { visibility }\end{array}$} & $\begin{array}{l}\text { no need for daily } \\
\text { or direct contacts } \\
\text { with the general } \\
\text { public, } \\
\text { catering to non-lo- } \\
\text { cal or local, most } \\
\text { often commercial } \\
\text { customers } \\
\end{array}$ & $\begin{array}{l}\text { Drewniano. } \\
\text { com } \\
(7) \\
\text { Green Car- } \\
\text { rot - Studio } \\
\text { Zabłocie } \\
(8)\end{array}$ \\
\hline $\begin{array}{l}\text { more peripheral locations } \\
\text { - outside areas considered } \\
\text { historic or artistic }\end{array}$ & $\begin{array}{l}\text { - lower costs; } \\
\text { - peace and quiet for artistic creation; } \\
\text { - an area's image not important as } \\
\text { artworks or pieces of design offered } \\
\text { not linked with a specific spatial } \\
\text { image or area. }\end{array}$ & & $\begin{array}{l}\text { no need for daily } \\
\text { or direct contacts } \\
\text { with customers, } \\
\text { focus on on-line } \\
\text { sales to non-local } \\
\text { customers }\end{array}$ & $\begin{array}{l}\text { Brasto } \\
(9) \\
\text { Tempera } \\
\text { Workshop } \\
(10)\end{array}$ \\
\hline
\end{tabular}

Source: own elaboration. 
residents with tastes different from their traditional more conservative bourgeois or working class counterparts and the general increase in the demand for creative goods and services visible in larger urban centres. It is also connected with the increasing flows of people to and from the city (i.e. thanks to connections by air and by new motorways), diffusion of new activities and organisational forms in the creative sector and emulation of patterns and ideas emerging in larger metropolitan centres serving as reference points for Kraków (e.g. London, Berlin, Warsaw), adapting them to local needs and conditions. Such changes and trends create opportunities for more enterprising individuals who search for new career paths different from the earlier modes of functioning in the art world. They provide possibilities to develop novel, more hybrid forms of activity combining artistic aims with business rationales.

Further longevity of such firms, however, will depend on the evolution of the general economic situation at local and national levels. The experience of artists who ran such enterprises but were forced out of business following the post-2008 cooling down of the economy show that this is a real threat. Therefore, apart from uncovering strategies and mechanisms of artists' entrepreneurial activities in urban space, our study also points out to the need for a well-thought-out public, in particular municipal, support for such enterprises which do not only contribute to the urban economy, but co-create unique atmosphere of particular quarters and sustain the cultural image of the city. They may, however, be fragile and highly dependent on the availability of usable spaces and affordable rent levels.

\section{Acknowledgements}

The text was written following the research carried out within the research project on 'Activities of artists in post-socialist cities: Socio-economic underpinnings and implications' conducted in 2013-2017 and financed with a grant awarded by the National Science Centre, Poland, grant agreement no. UMO-2012/05/E/HS4/01601. The authors wish to thank all artists who took part in it. They are also very grateful to two anonymous reviewers for their insightful comments on the earlier draft of the paper.

\section{References}

Aggestam M., 2007. Art-entrepreneurship in the Scandinavian music industry. In: Henry C. (ed.), Entrepreneurship in the creative industries: An international perspective. Edwin Elgar, Cheltenham: 30-53.

Blaug M., Towse R., 2011. Cultural entrepreneurship. In: Towse R. (ed.), Handbook of cultural economics, second edition. Edward Elgar, Cheltenham: 153-157.

Bogacz-Wojtanowska E., Hojda P., Wrona S., Szladowski M., Siorek B., 2018. Badanie losów zawodowych absolwentów uczelni (Research on professional careers of graduates of art schools). Raport ogólny z panelowych badań ilościowych. ASP w Krakowie, Kraków.

Cambridge Dictionary, 2019. Entrepreneur. https://dictionary.cambridge.org/dictionary/english/entrepreneur (accessed: 28 February 2019).

Chapain C., Stryjakiewicz T. (eds), 2017. Creative industries in Europe. Drivers of new sectoral and spatial dynamics. Springer, Cham.

Cunningham J., Tolonen K.M., 2019. Maintaining the scene: Entrepreneurship in Berlin's artistic sectors. International Journal of Entrepreneurship and Small Business 37(4): 492512.

Debroux T., 2013. Les territoires creatifs: Quelques notions theoriques et une analyse bruxelloise. Territoire en Mouvement 19-20(2): 40-59. DOI: 10.4000/tem.2128.

Działek J., Murzyn-Kupisz M., 2014. Young artists and the development of artistic quarters in Polish cities. Belgeo 3. DOI: $10.4000 /$ belgeo.13012.

Działek J., Murzyn-Kupisz M., 2017. Do artists need artistic quarters? Spatial preferences and choices of artists in Kraków. In: Murzyn-Kupisz M., Działek J. (eds), The impact of artists on contemporary urban development in Europe. Springer, Cham: 91-120.

Grodach C., 2013. Cultural economy planning in creative cities: Discourse and practice. International Journal of Urban and Regional Research 37(5): 1747-1765.

Heebels B., van Aalst I., 2010. Creative clusters in Berlin: Entrepreneurship and the quality of place in Prenzlauer Berg and Kreuzberg. Geografiska Annaler: Series B, Human Geography 92(4): 347-363.

Hracs B., 2009. Beyond bohemia: Geographies of everyday creativity for musicians in Toronto. In: Edensor T., Leslie D., Millington S., Rantisi N. (eds), Spaces of vernacular creativity: Rethinking the cultural economy. Routledge, London: 75-88.

Hutton T., 2016. Cities and the cultural economy. Routledge, London.

Karjalainen P.T., 2003. On geobiography. In: Sarapik V., Tüür K. (eds), Place and location: Studies in environmental aesthetics and semiotics III. Estonian Literary Museum, Tartu: 87-92.

Kim J.Y., 2016. Cultural entrepreneurs and urban regeneration in Itaewon, Seoul. Cities 56: 132-140.

Kolb B.M., 2015. Entrepreneurship for the creative and cultural industries. Routledge, London.

Krätke S., 2011. The creative capital of cities: Interactive knowledge creation and the urbanization economies of innovation. Wiley-Blackwell, Chichester.

Lange B., 2009. Accessing markets in creative industries professionalization and social-spatial strategies of culturepreneurs in Berlin. Creative Industries Journal 1(2): 115-135. 
Leadbeater C., Oakley K., 1999. The independents: Britain's new cultural entrepreneurs. Demos, London.

Markusen A., 2014. Creative cities: A 10-year research agenda. Journal of Urban Affairs 36(2): 567-589.

Mazurkiewicz P., 2017. Polscy jubilerzy z roku na rok błyszczą coraz słabiej. Rzeczpospolita, 14 March 2017.

Menger P.-M., 1999. Artistic labour markets and careers. Annual Review of Sociology 25(1): 541-574.

Montgomery J., 2007. The new wealth of cities. City dynamics and the fifth wave. Ashgate, Aldershot.

Murzyn-Kupisz M., Działek J., 2017a. Artyści w przestrzeni miejskiej Krakowa i Katowic. Universitas, Kraków.

Murzyn-Kupisz M., Działek J. (eds), 2017b. The impact of artists on contemporary urban development in Europe. Springer, Cham.

Namyślak B., 2013. Działalności twórcze a rozwój miast. Przykład Wrocławia. Uniwersytet Wrocławski, Wrocław.

Niemczyńska M., 2014. Trzy razy Lokator. Tygodnik Powszechny, 15 December 2014.

Oakely K., 2014, Good work? Rethinking cultural entrepreneurship. In: Bilton C., Cummings S. (eds), Handbook of management and creativity. Edward Elgar, Cheltenham: 145-159.

Pasquinelli C., Sjöholm J., 2015. Art and resilience: The spatial practices of making a resilient artistic career in London. City, Culture and Society 6(3): 75-81.

Pratt A.C., Hutton T.A., 2013. Reconceptualising the relationship between the creative economy and the recession: Learning from the financial crisis. Cities 33: 86-95.

Rae D., 2007. Creative industries in the UK: Cultural diffusion or discontinuity? In: Henry C. (ed.), Entrepreneurship in creative industries: An international perspective. Edward Elgar, Cheltenham: 54-71.

Rius-Ulldemolins J., 2012. Gallery districts of Barcelona: The strategic play of art dealers. The Journal of Arts Management, Law, and Society 42(2): 48-62.

Scherdin M., Zander I. (eds), 2011. Art entrepreneurship, Edward Elgar, Cheltenham.
Scott M., 2012. Cultural entrepreneurs, cultural entrepreneurship: Music producers mobilising and converting Bourdieu's alternative capitals. Poetics 40(3): 237-255.

Smit A.J., 2011. The influence of district visual quality on location decisions of creative entrepreneurs. Journal of the American Planning Association 77(2): 167-184.

Środa-Murawska S., Szymańska D., 2013. The concentration of the creative sector firms as a potential basis for the formation of creative clusters in Poland. Bulletin of Geography. Socio-economic Series 20: 85-93.

Stachowiak K., 2017. Gospodarka kreatywna i mechanizmy jej funkcjonowania. Perspektywa geograficzno-ekonomiczna (Creative economy and mechanisms of its functioning. A geographical and economic perspective). Uniwersytet im. A. Mickiewicza, Poznań.

Stryjakiewicz T., Męczyński M., Stachowiak K., 2014. Role of creative industries in the post-socialist urban transformation. Quaestiones Geographicae 33(2): 19-35, DOI 10.2478/ quageo-2014-0013.

Suwala L., 2015. Cultural entrepreneurship. In: Wherry F.F., Schor J. (eds), The Sage encyclopaedia of economics and society. Sage, Los Angeles: 513-515.

Swedberg R., 2006. The cultural entrepreneur and the creative industries: Beginning in Vienna. Journal of Cultural Economics 30(4): 243-261.

Throsby D., 2001. Economics and culture. Cambridge University Press, Cambridge.

Tomczak P., Stachowiak K., 2015. Location patterns and location factors in the cultural and creative industries. Quaestiones Geographicae 34(2): 7-27.

Towse R., (2010). A textbook of cultural economics. Cambridge University Press, Cambridge.

Wedd K., Pettz L., Ross C., 2001., Creative quarters: The art world in London from 1700 to 2000. Museum of London, London.

Zukin S., Braslow L., 2011. The life cycle of New York's creative districts: Reflections on the unanticipated consequences of unplanned cultural zones. City, Culture and Society 2(3): 131-140. 